\title{
OPTIMISATION OF EARTH QUAKE RESPONSE OF TALL BUILDING BY USING DIFFERENT FRAMING SYSTEMS OVER THE HEIGHT
}

\author{
Sajeet.S.B ${ }^{1}$, Shashinag N N ${ }^{2}$ \\ ${ }^{1}$ Structural Engineer, Prasad Consultant, Bangalore, Karnataka, India \\ ${ }^{2}$ Post Graduate Student In Structural Engineering, BGS, Bangalore, Karnataka, India
}

\begin{abstract}
In India reinforced concrete structures are mostly used since this is the most convenient \& economic system for low-rise buildings. However, for medium to high-rise buildings this type of structure is no longer economic because of increased dead load, less stiffness, span restriction and hazardous formwork. So the Structural engineers are facing the challenge of striving for the most efficient and economical design solution. Also Earthquake engineering should be extended to the design of earthquake sensitive tall buildings. Use of composite material is of particular interest, due to its significant potential in improving the overall performance through rather modest changes in manufacturing and constructional technologies.

In India, many consulting engineers are reluctant to accept the use of composite steel-concrete structure because of its unfamiliarity and complexity in its analysis and design. But literature says that if properly configured, then composite steelconcrete system can provide extremely economical structural systems with high durability, rapid erection and superior seismic performance characteristics.
\end{abstract}

This paper discusses Optimization of Earth quack response of tall building by using different types of framing system over the height of the building. So to optimize the earth quack response, a Ten story Combined model ( R.C.C, Composite and Steel frames) is developed and analyzed by using ETABS; it proves that the combined model is better option.

Key Words: Composite structure, Tall Building and Steel structures

\section{General}

Now a days the tall building are constructed by famed structure it is define by beams, columns and slabs. The vertical members are called columns and horizontal members are called beams and planes are called slabs. The columns are the primary load carrying element and it is very important in frames. If we damage beam it usually affect only one floor but damage column could bring down entire structure. The beams and columns are interconnected at joints by using rebar this type of connection is called moment connection. This connection can withstand against the lateral force. The lateral force is wind load and earthquake load. Most probably concrete is considered as rigid material this may not affect the single storey or two storey building but for a tall structures it affect because of its rigid property. As a civil engineer our main intension is too built as flexible as possible. For a rigid structures earthquake influences large amount of damage so to overcome this we have to build up flexible structures. It has lead us to implement advanced and improved lateral load resisting systems for operative and effective moderation of earthquake force.

\subsection{Objectives}

The objectives of this study can be listed as follows

$>$ To study the earthquake response of Different framing systems like RCC, Steel \& Composite by response spectrum analysis.

$>$ To study the earthquake response of combined framing systems over the height of the building by response spectrum analysis.

$>$ To compare above two points.

\subsection{Present Study}

This paper discusses Optimization of Earth quack response of tall building by using different types of framing system over the height of the building. So to optimize the earth quack response, a Ten story Combined model ( R.C.C, Composite and Steel frames) is developed and analyzed by using ETABS ; it proves that the combined model is better option.

\section{Response Spectrum Analysis}

The procedure to compute the peak response of structure during the earthquake directly from the earthquake response spectrum without the need of time history analysis is called response spectrum analysis.

Response spectrum is a plot of maximum response of a SDF for various value of the period for a given input. The IS1893 gives an average Response spectrum can be employed in earthquake resistant design. 


\subsection{Strucural Model}

For this study, building with ten storeys is considered. The Dimension of all the buildings is exactly same i.e. $20 \mathrm{~m} \mathrm{x}$ $12 \mathrm{~m}$. The structural models have the same story height of $3 \mathrm{~m}$.and have a uniform mass distribution over their height. The horizontal beam spacing is $3 \mathrm{~m}$ and vertical beam spacing is $4 \mathrm{~m}$. Building plan is shown is below fig.3.2.a

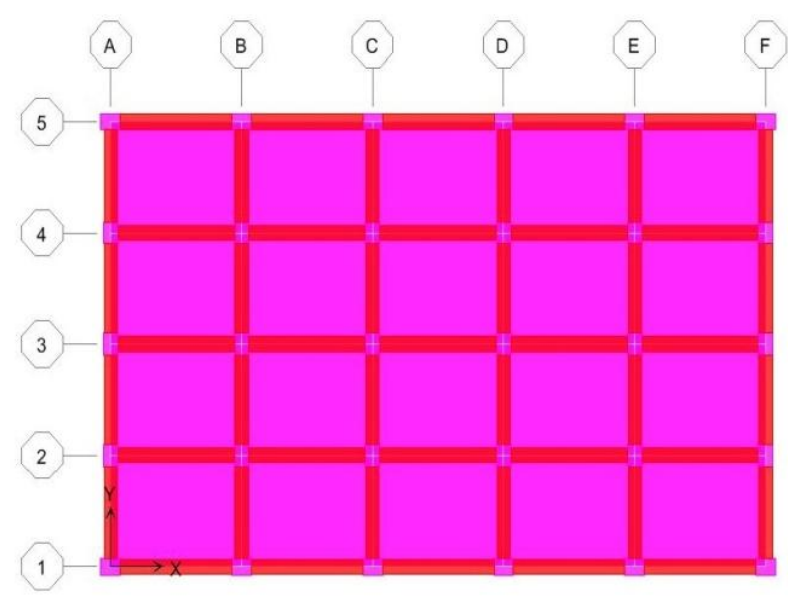

Fig.3.2.a L RCC model and building plan

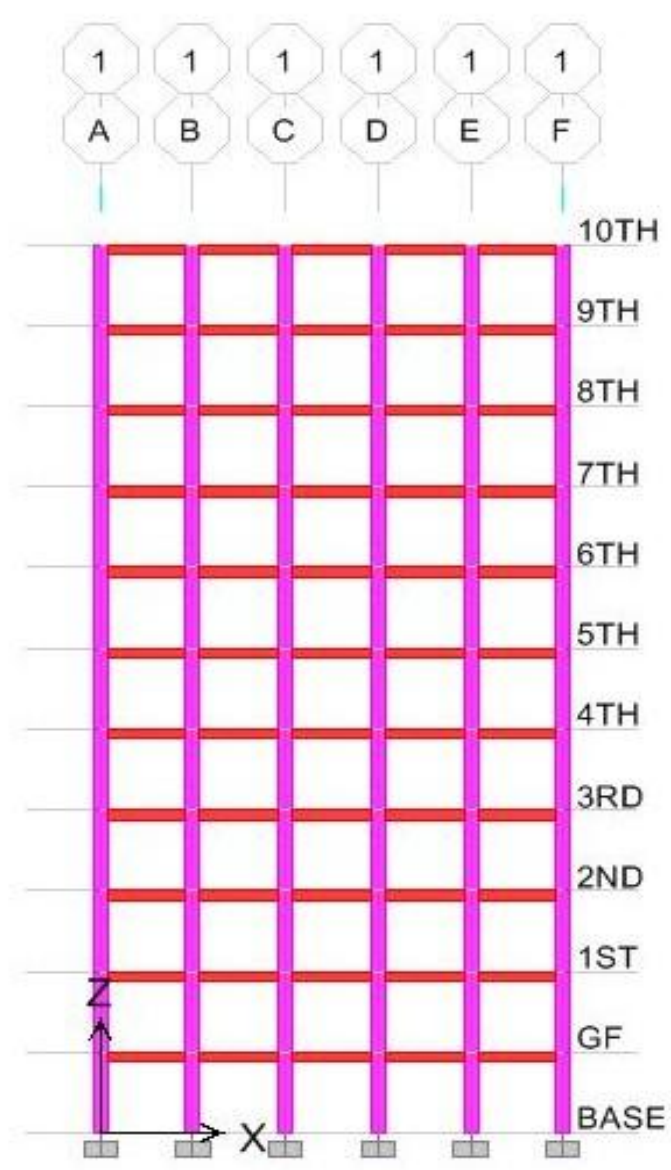

fig.3.2.b RCC Building Elevation

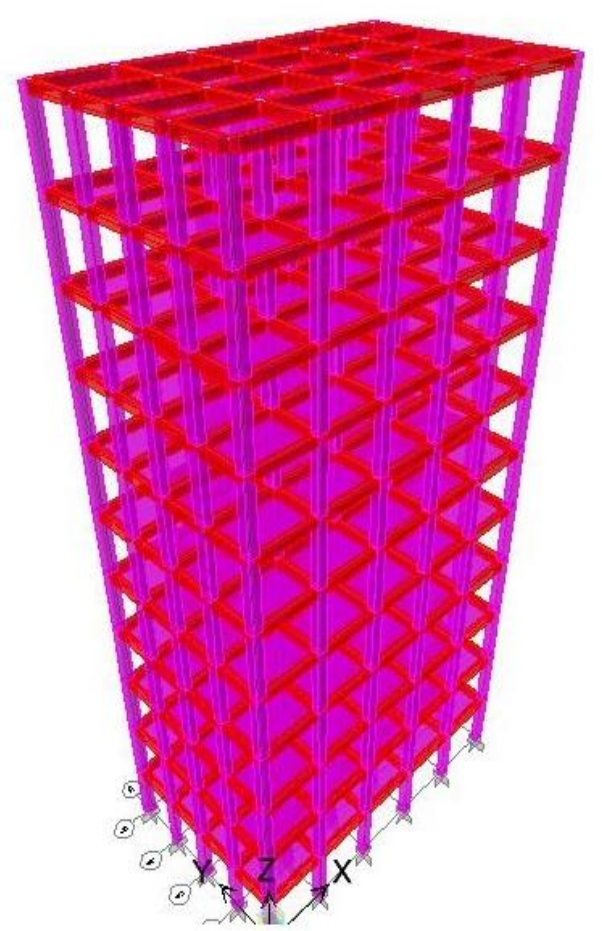

fig.3.2.c RCC model 3D View

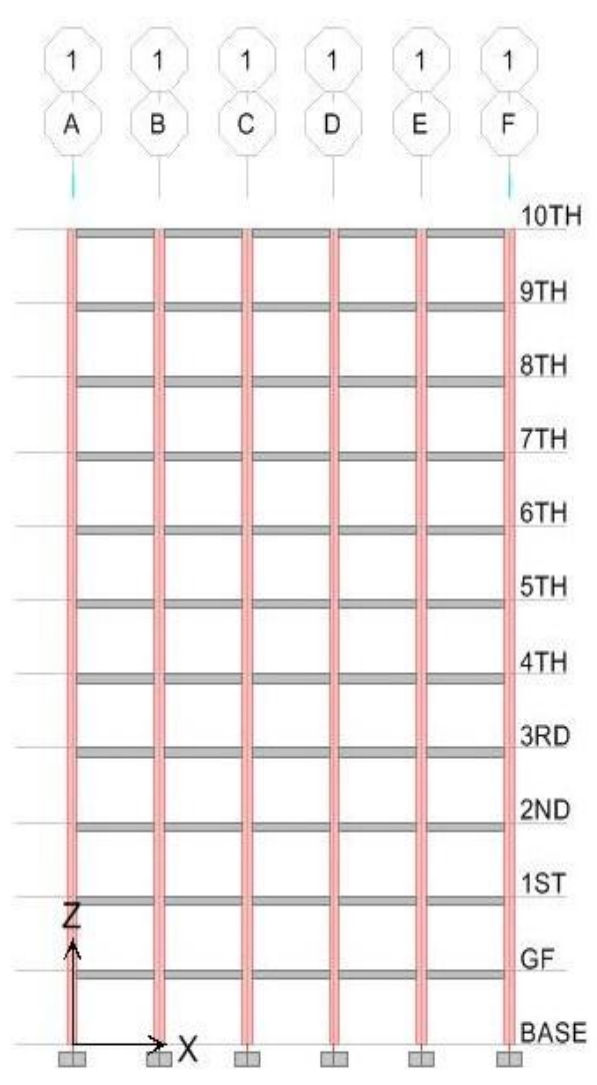

fig.3.2.d STEEL model Elevation 


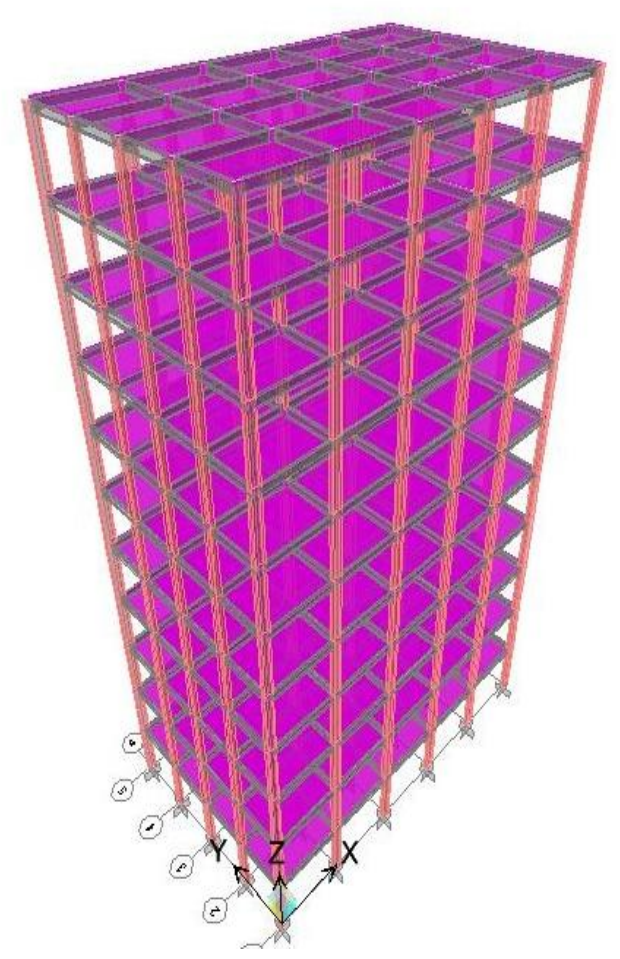

fig.3.2.e STEEL model 3D View

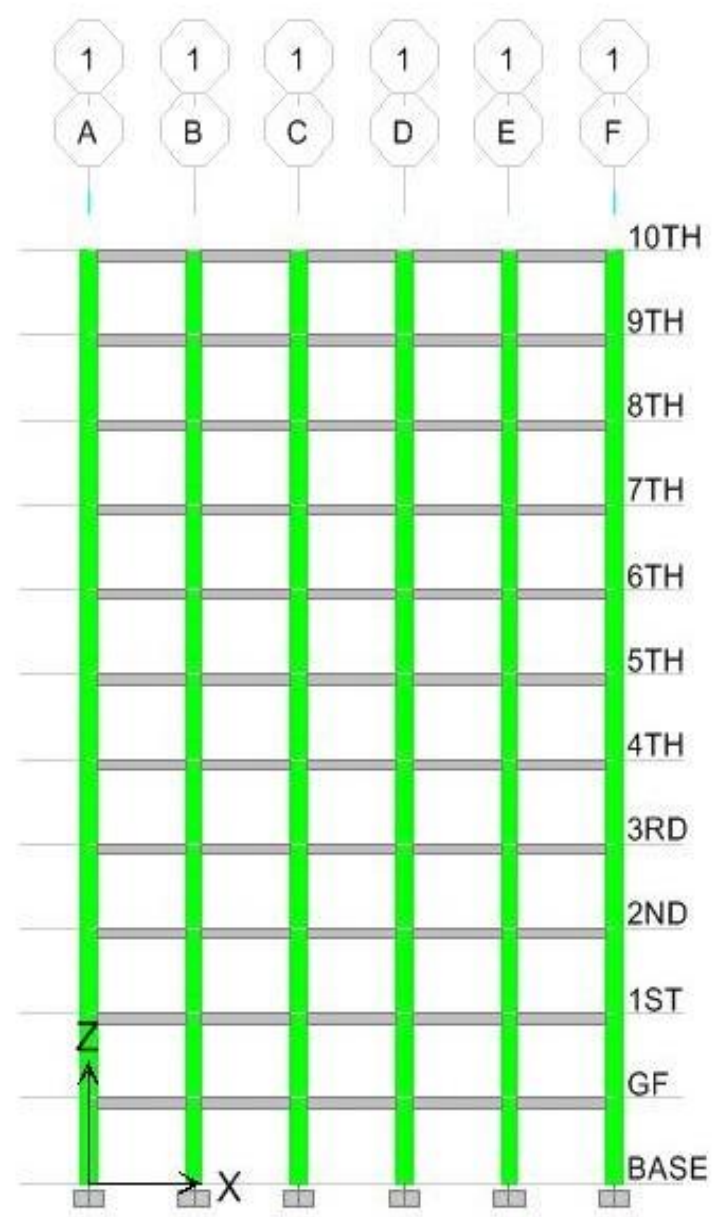

fig.3.2.f COMPOSITE model Elevation

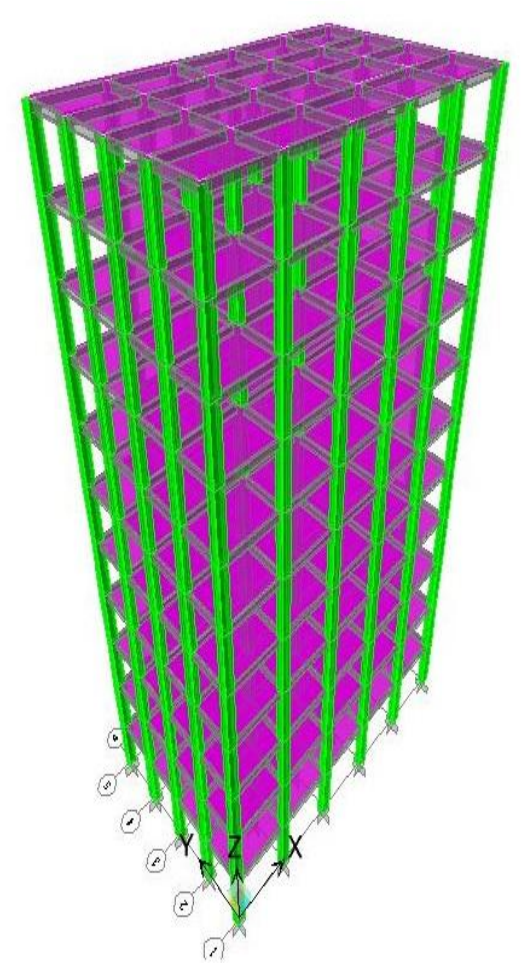

fig.3.2.g COMPOSITE model 3D View

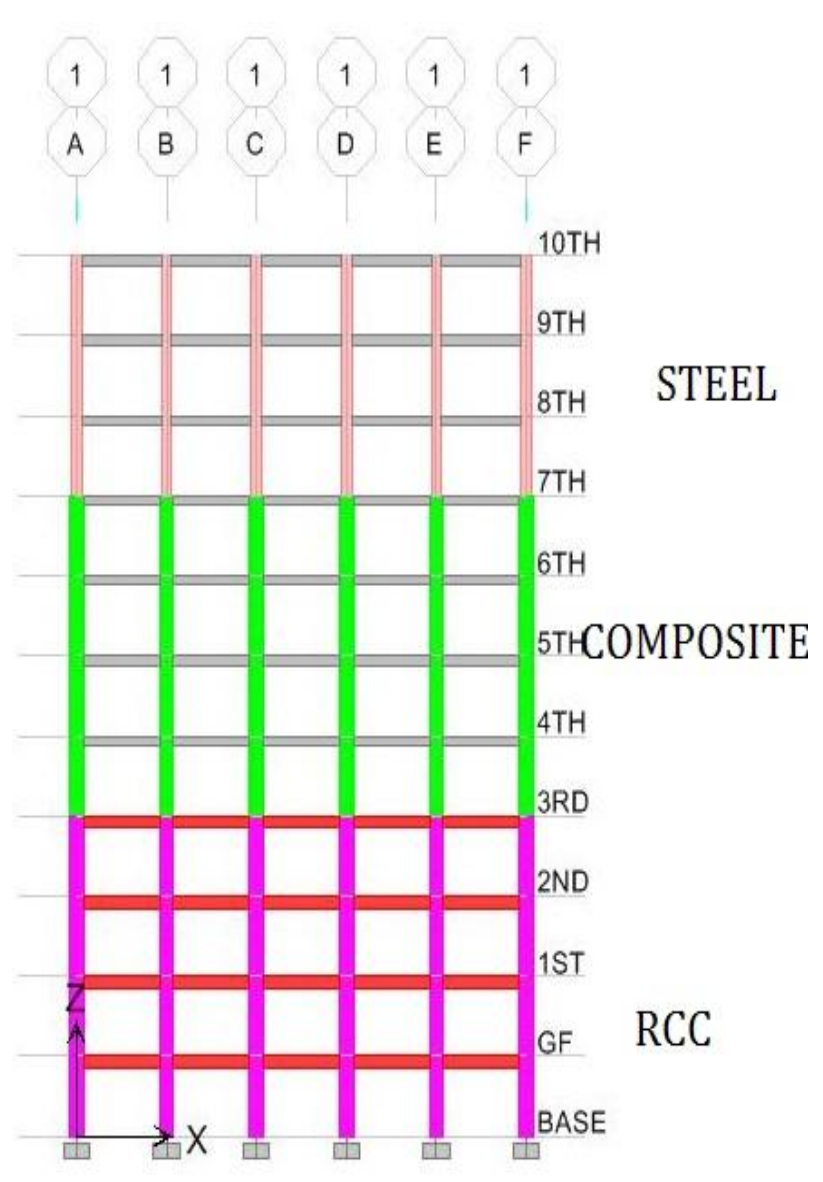

fig.3.2.h COMBINED model Elevation 


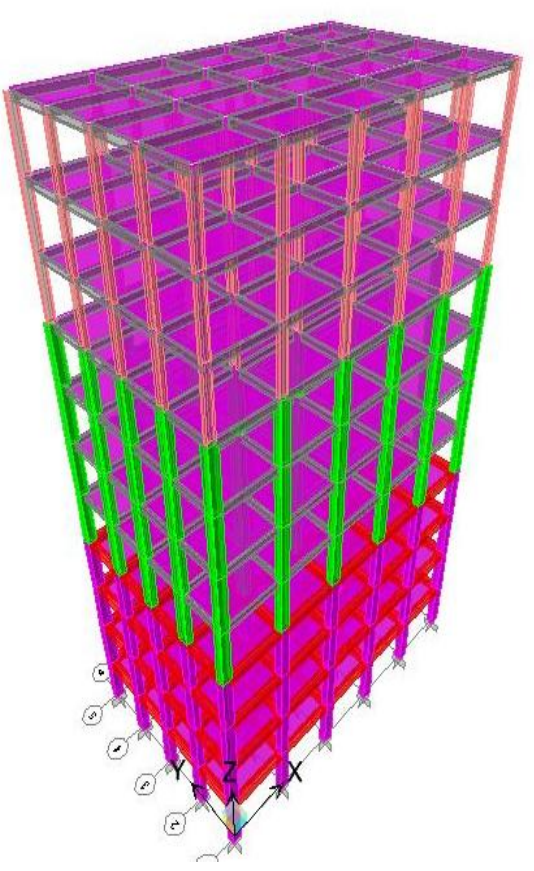

fig.3.2.i COMBINED model 3D View

\begin{tabular}{|c|c|}
\hline $\begin{array}{c}\text { MODEL TYPE } \\
\text { MATERIAL PROPERTIES }\end{array}$ & $\begin{array}{c}\text { ALL } \\
\text { Model }\end{array}$ \\
\hline Column / Wall & M45 \\
\hline Beam & M25 \\
\hline Slab & M25 \\
\hline
\end{tabular}

\subsection{Input Details}

Table 1- Structural Sections Detail

\begin{tabular}{|l|l|l|l|r|}
\hline & & COL & BEAM & SLAB \\
\hline & 7 TO 10 & $450 X 600$ & $400 X 450$ & 150 \\
\hline TYPE1 & 3 TO 7 & $450 X 600$ & $400 X 450$ & 150 \\
\hline & B-3 & $450 X 600$ & $400 X 450$ & 150 \\
\hline TYPE2 & 3 TO 10 & ISMB450 & ISMB350 & 150 \\
\hline & B-3 & ISMB450 & ISMB350 & 150 \\
\hline & 7 TO 10 & C+ISMN450 & ISMB350 & 150 \\
\hline TYPE3 & 3 TO 7 & C+ISMN450 & ISMB350 & 150 \\
\hline & B-3 & C+ISMN450 & ISMB350 & 150 \\
\hline & 7 TO 10 & ISMB450 & ISMB350 & 150 \\
\hline TYPE4 & 3 TO 7 & C+ISMN450 & ISMB350 & 150 \\
\hline & B-3 & $450 X 600$ & $400 X 450$ & 150 \\
\hline & & & & \\
\hline
\end{tabular}

Table 2-Seismic Loading Zone As Per Is:1893

\begin{tabular}{|c|c|}
\hline DETAIL & VALUE \\
\hline $\mathrm{R}$ & 3 \\
\hline $\mathrm{I}$ & 1 \\
\hline $\mathrm{Z}$ & .10 \\
\hline $\mathrm{Sa} / \mathrm{G}$ & Type 2 \\
\hline $\mathrm{Z}=$ Zone & $\mathrm{Sa} / \mathrm{g}=$ Soil type II, \\
\hline
\end{tabular}

$\mathrm{R}=$ response reduction factor $\mathrm{I}=$ Importance factor

Table 3-Material Properties

Density of concrete: $25 \mathrm{KN} / \mathrm{m} 3$

Slab thickness: $150 \mathrm{~mm}$

wall thickness: $200 \mathrm{~mm}$

\subsection{Static Load Assignment}

The loads considered are

Dead Load, Live Load, Floor Finish, and Earth Quake Load. All models consist of these loads.

Dead Load: The dead load of the structure is obtained from Table 1, Page 8, of IS 875 - Part 1 - 1987. The permissible value for unit weight of reinforced concrete varies from $24.80 \mathrm{kN} / \mathrm{m}^{3}$ to $26.50 \mathrm{kN} / \mathrm{m}^{3}$. From the table, the unit weight of concrete is taken as $25 \mathrm{kN} / \mathrm{m}^{3}$. The software has a inbuilt DL calculator

Self-weight of the structural elements Floor finish $=2 \mathrm{kN} / \mathrm{m}^{2}$

Imposed Load: The imposed load on the floor is obtained from Table 1 of IS 875 (Part 2) - 1987. The uniformly distributed load on the floor of the building is assumed to be $4.0 \mathrm{kN} / \mathrm{m}^{2}$ (for assembly areas, corridors, passages, restaurants business and office buildings, retail shops etc).

On roof $1.5 \mathrm{kN} / \mathrm{m}^{2}$, and

On floors $4.0 \mathrm{kN} / \mathrm{m}^{2}$

Earth Quake Load: The structure is assumed to be in Zone-II as per IS $1893-2002$. So the zone factor is taken as per Table 2 of IS $1893-2002$. The damping is assumed to be 5\%, for concrete as per Table 3 of IS 1893-2002. Importance factor is taken as 1 as per Table 6 of IS $1893-$ 2002.

Zone II, Soil type II, Importance factor $=1$

Response Reduction Factor, in this case the values of $\mathrm{R}$ are defined $. R=3$ is used.

Load combinations: The load combinations is obtained from page no13, clause 6.3.1.2 of. IS $1893-2002$. 
DLEQX $=1.2(\mathrm{DL}+\mathrm{LL}+\mathrm{SPECX})$

DLEQY=1.2(DL+LL+SPECY)

Table 4-Analysis Input

\begin{tabular}{|c|c|}
\hline RYPS OF MODELS & ALL \\
\hline Function input & $\mathrm{R}=3$ \\
\hline spectrum case name & 0.1 \\
\hline structural and function damping & $\mathrm{spec} 1$ \\
\hline model combination & 0.05 \\
\hline directional combination & $\mathrm{CQC}$ \\
\hline input response spectra & $\mathrm{SRSS}$ \\
\hline eccentricity ratio & $9.81 / 2 * 3$ \\
\hline
\end{tabular}

\section{ANALYSIS AND RESULTS}

\subsection{FREQUENCY AND TIME PERIOD}

The value of $\mathrm{T}$ depends on the building flexibility and mass; more the flexibility, the longer is the period and more the mass, the longer is the period.

From below fig... the maximum time period is in TYPE 2 model and minimum time period is in TYPE 4 model. Therefore one can say that TYPE 4 model has more flexibility and mass when compared to other models.

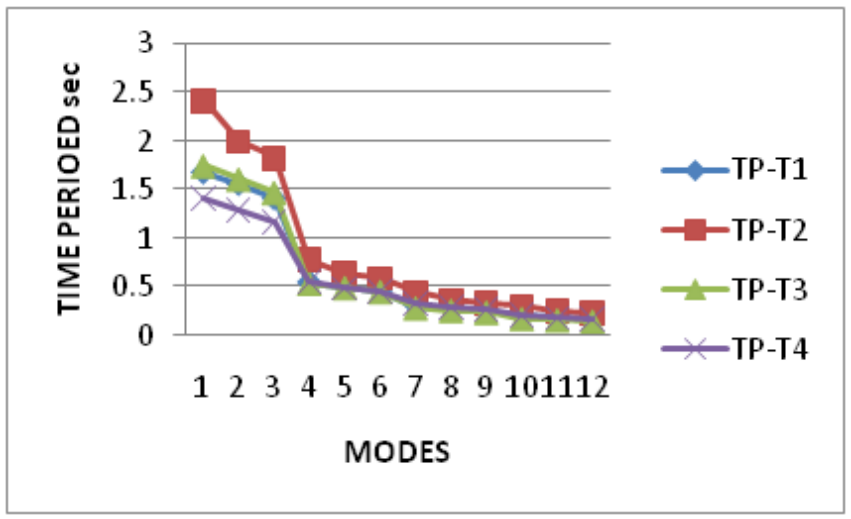

Fig -1: Time perioed vs modes

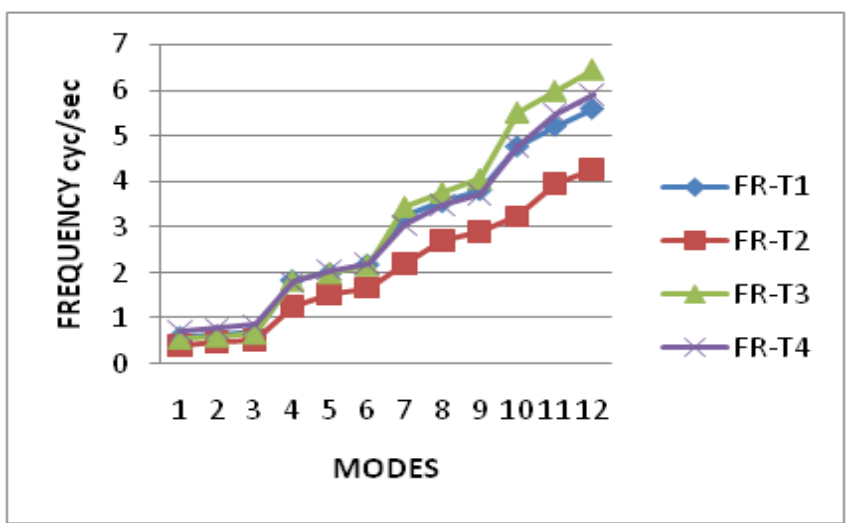

Fig -2: Frequency vs modes

\subsection{Displacement ( $\mathrm{mm})$}

As it can be seen from below figures, the displacement of the stories of structures is reduced by developing a TYPE 4 model. In addition to the results of all models the maximum displacement is in TYPE 2 model and minimum displacement is in TYPE 4 model. Furthermore the graph shows that there has been steady increase in the amount of displacement of stories over the height.

According to this work, the reduction of displacement of stories is due to increase of stiffness of structure as well as decrease of velocity and acceleration of structure. In other words by creating the TYPE 4 model, the response of structure such as velocity and acceleration can be reduced and it is the cause of reduction of displacement.

On Observing, displacements at all the storey in the TYPE 4 model is less than those in Other model. Here as one can see displacements lowest in bottom stories, very high at the upper stories.

The displacement is of interest with regard to structural stability, strength and human comfort. The displacement of TYPE 4 model is less than the other model. It means that

Structure is more stable

Chance of Structural Strength reduction is less.

Human comfort is good.

\section{EARTH QUAKE IN X-DIRECTION}

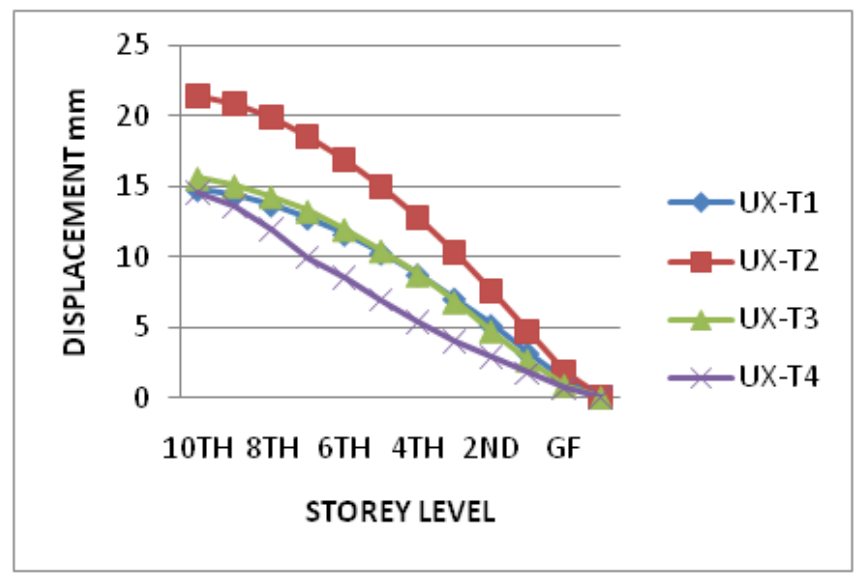

Fig 3: Displacement-x vs Storey level 


\section{EARTH QUAKE IN Y-DIRECTION}

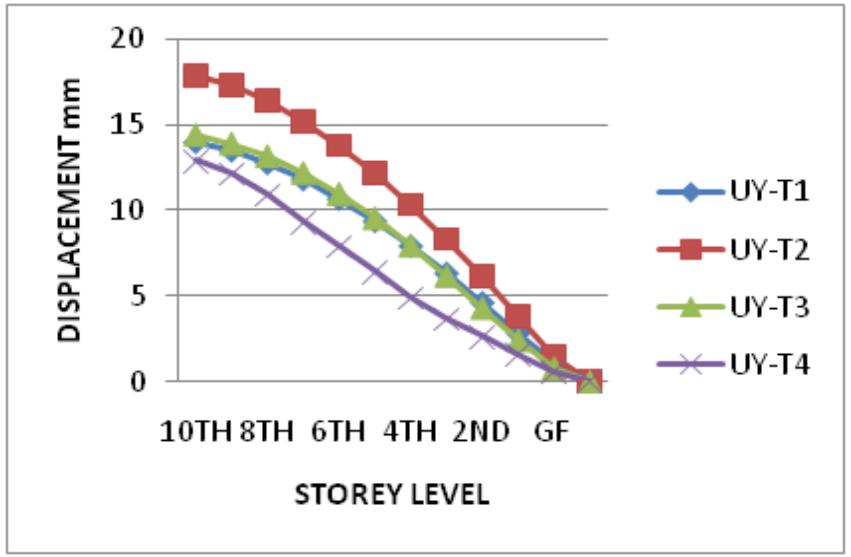

Fig 4: Displacement-y vs Storey level

\subsection{STORY DRIFT RATIO}

It is the displacement of one level relative to the other level above or below.

The building may collapse due to different response quantities. For eg., at local levels such as strains, curvatures, rotations and at global levels such as interior story drifts.

Individual stories may exhibit excessive lateral displacement. Therefore it can be concluded that by decreasing the story drifts of structure, the probability of collapse of the building can be reduced. To do that, as it is mentioned, TYPE 4 model can play a significant rule to reduce response of structure.

On Observing, storey drift ratios at all the stories in the TYPE 4 model are less than those in Other model at middle stories. Here as one can see the storey drift ratio pattern is totally different from other model i.e very low in bottom stories and finally increases towards the upper stories. But in other models, very low in bottom stories, very high at the middle stories and finally decreases towards the upper stories.

\section{EARTH QUAKE IN X-DIRECTION}

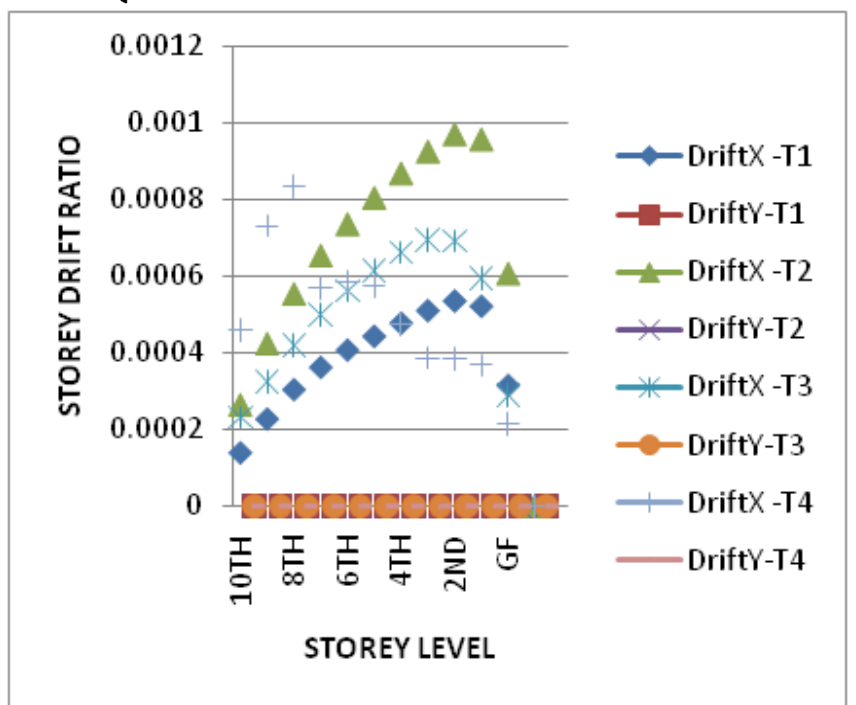

Fig 5: storey drift ratiot-x vs Storey level

\section{EARTH QUAKE IN Y-DIRECTION}

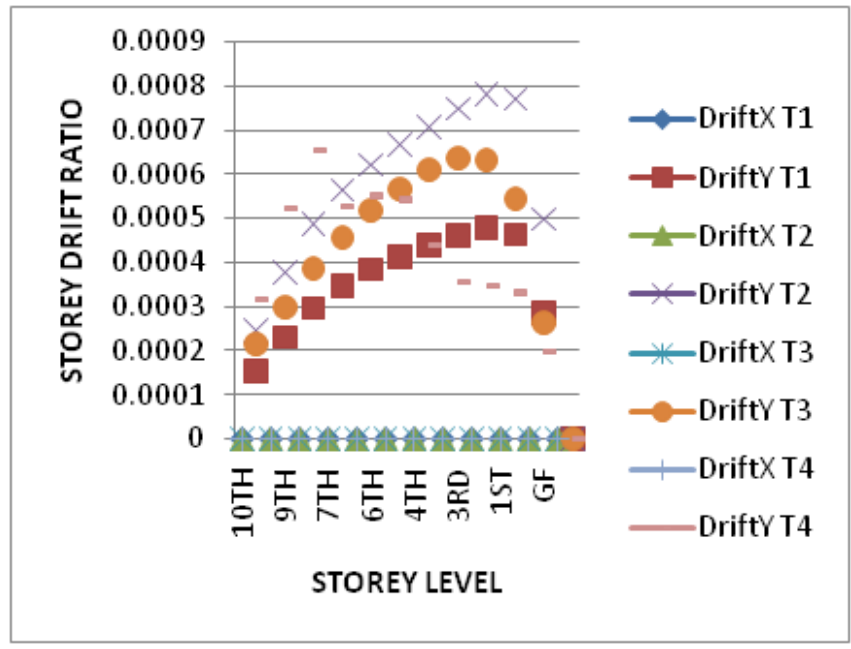

Fig 6: storey drift ratiot-y vs Storey level

\subsection{STORY SHEAR $(k N)$}

It is the sum of design lateral forces at all levels above the storey under consideration.

As it can be seen from below figures, the maximum story shear is in TYPE 1 model and minimum story shear in TYPE 2 model. Furthermore the graph shows that there has been steady decreasing in the amount of story shear over the height. In all models, the story shear at the base is more and at the top story shear is less. But when we compare All models, the minimum story shear is in TYPE1 model and maximum is in TYPE 2 model.

The storey shear of Type 4 model is almost equal to

TYPE 1.

\section{EARTH QUAKE IN X-DIRECTION}

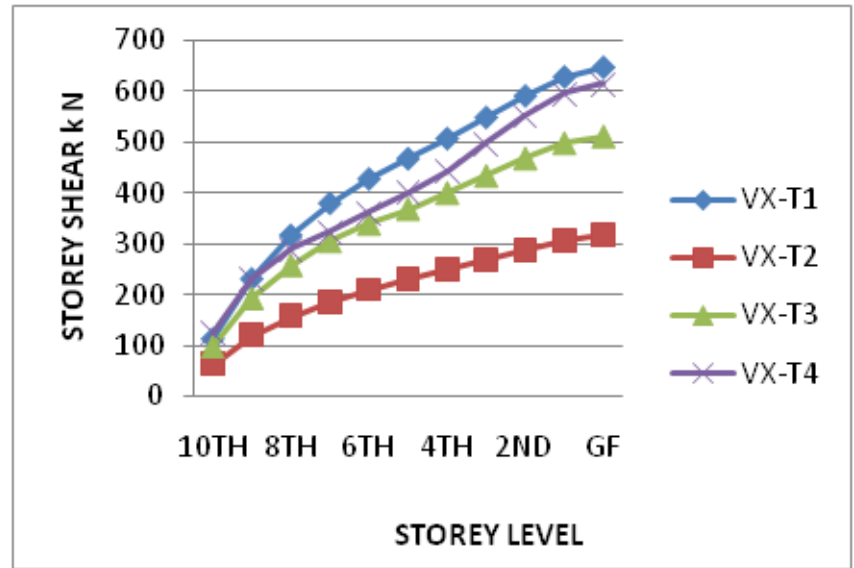

Fig 7: storey shear-x vs Storey level 


\section{EARTH QUAKE IN Y-DIRECTION}

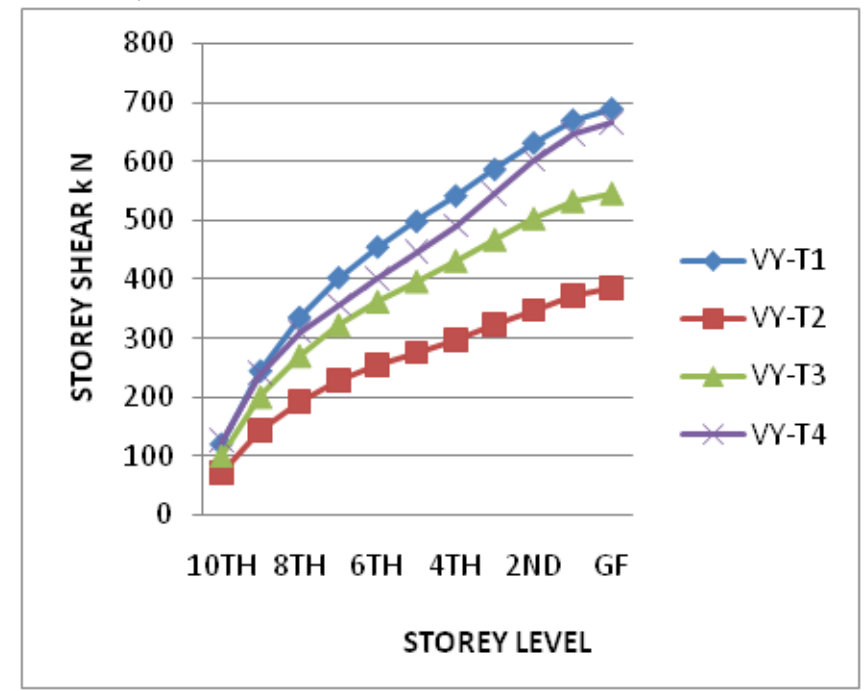

Fig 8: storey shear-y vs Storey level

\section{CONCLUSION}

\section{RESPONSE SPECTRUM ANALYSIS}

In the present work a 10 storied structure is designed as per IS 456 \& IS1893. It is observed that the combine model shows significant reduction in time period, displacements \& drift ratio.

Thus the work shows that it is possible to reduce the seismic response by a using combine structure.

\section{REFERENCES}

[1]. Shweta A. Wagh, Dr. U. P. Waghe Comparative Study of R.C.C and Steel Concrete Composite Structures. Int. Journal of Engineering Research and Applications www.ijera.com ISSN: 2248-9622, Vol. 4, Issue 4(Version 1), April 2014, pp.369-376

[2]. Alessandro Zona, Michele Barbato, and Joel P. Conte, Nonlinear Seismic Response Analysis of Steel-Concrete Composite Frames Journal of structural engineering ( ASCE / JUNE 2008

[3]. Mahesh suresh kumawat, analysis and design of multi storey building using composite structures. . Int. Journal structural and civil engineering research vol. 3, 2014

[4]. D. R. Panchal and P. M. Marathe, Comparative Study of R.C.C, Steel and Composite (G+30 Storey) Building. Institute of technology, Nirma University, AHMEDABAD 382 481, 08-10 DECEMBER, 2011 